\title{
Clean Energy Certification in Brazil: A proposal
}

\author{
Fernando Amaral de Almeida Prado Jr. ${ }^{* 1}$, Ana Lúcia Rodrigues da Silva ${ }^{2}$, Edvaldo \\ Marcelo Avila ${ }^{3}$, Gustavo Matsuyama \\ ${ }^{1}$ Faculdade de Engenharia Civil UNICAMP, Sao Paulo, Brazil \\ e-mail: fernando@sinerconsult.com.br \\ ${ }^{2}$ Senac Campos do Jordão, Sao Paulo, Brazil \\ ${ }^{3}$ Comerc Energia, Sao Paulo, Brazil \\ ${ }^{4}$ Sinerconsult Consultoria Treinamento e Participações Limitada, Sao Paulo, Brasil
}

Cite as: de Almeida Prado Jr., F. A., Rodrigues da Silva, A. L., Avila, E. M., Matsuyama, G., Clean Energy

Certification in Brazil: A proposal, J. sustain. dev. energy water environ. syst., 3(1), pp 95-105, 2015, DOI: http://dx.doi.org/10.13044/j.sdewes.2015.03.0007

\begin{abstract}
Given the overwhelming scientific evidence on climate change, voluntary reduction of greenhouse gas emissions is becoming increasingly important, especially as diplomatic efforts to secure the commitment of United Nations has proven ineffective. Brazil believes its energy matrix is sufficiently renewable and clean. This may be the reason why there aren't more official efforts to certify reduced emissions due to the use of clean energy sources. Nevertheless, there are financial incentives for using clean energy sources. In order to avoid the misuse of financial incentives, the electricity regulator in Brazil has developed strict supervision methodology. However, there is no data on avoided emissions. Herein we propose a methodology to certify greenhouse gas (GHG) emission reductions using best principles of governance. This methodology is based on official data, calculates the emissions avoided and the equivalent reforestation required to produce the same effect, thus making the results tangible for a less specialized audience. We also describe our practical experience with 120 consuming units that add up to over $1,500 \mathrm{GWh} /$ year.
\end{abstract}

\section{KEYWORDS}

Climate change, Emissions reduction, Voluntary reduction, Reforestation, Certification.

\section{INTRODUCTION}

This article focuses on voluntary initiatives that contribute to reducing GHG emissions. Our main goal here is to develop a clean energy certification program process and encourage its use in Brazil, a country that still has no official methodology for recording and keeping track of GHG emission abatement from the use of renewable energy sources.

What drives us to this objective?

The Conference of Parties (COPs) has been unable to significantly promote diplomatic agreement, and it is unlikely that the US will adhere to international commitments unless high-emitting developing nations do the same. If emerging nations, and in particular India, China, Brazil and Indonesia adhere to the commitments, the situation could be different.

We believe that government measures and coordinated actions under the umbrella of UN agreements alone will not be enough to fight climate change. Thus, in addition to

\footnotetext{
* Corresponding author
} 
government initiatives and related legislation, new and better market tools and voluntary self-regulation are required.

This is a hugely serious matter, as for the very first time in 3 million years the concentration of $\mathrm{CO}_{2}$ in the atmosphere has passed the 400-ppm mark. This level means that we will have to cope with climate change for a long time, as it seems inevitable that temperatures will rise by at least $2{ }^{\circ} \mathrm{C}$.

Thousands of references in scientific publications from all over the world confirm a worsening trend in Climate Change. One example would be the $4^{\text {th }}$ IPCC Report [1]. Other examples of the many publications on this topic that describe the anthropogenic effects on climate change are those by Mann [2, 3], Dell [4], Thompson [5] and the National Research Council [6].

However, there is no unanimity about how to tackle climate change, or even if it needs to be tackled. Those who oppose the need to address climate change normally (1) discredit the existence of the climate change phenomenon, (2) recognize that climate change exists, but play down its effects and consequences, or (3) recognize the phenomenon but do not accept it is at all anthropogenic. Regardless of what they base their arguments on, they all believe there is nothing humans can do to reverse or fight the effects of climate change. Among the publications opposing or skeptical of the climate change argument are those by Lal [7], Carter [8], Idso [9], Milloy [10] and Lomborg [11].

\section{VOLUNTARY MARKETS}

Many businesses have received incentives to develop initiatives to reduce GHG emissions.

Even the US, which has yet to adhere to formal agreements and remains a paradigm of resisting international cooperation, has hundreds of initiatives to reduce emissions. Here we list some of the strategies that have been used, including by nations with no objective obligation to reduce GHG emissions:

- Regional legislation;

- Sectorial policies;

- Initiatives by industry associations, unions and NGOs;

- Business initiatives.

Each of these initiatives has its own motivations, and may or may not be facilitated by the boundary conditions of each industry.

Take for example the Carbon Disclosure Project (CDP), which in 2012 involved more than 400 companies listed in the Global 500 index. Initiatives such as this one can further best practices around the world by helping people and companies think strategically about climate change.

The 2012 CDP Report shows that $82 \%$ of the companies listed in the CDP initiative have set targets to reduce emissions. If met, these would account to $25 \%$ of the required GHG abatement to keep global warming to no more than $2{ }^{\circ} \mathrm{C}$.

A review of the literature on voluntary markets (Desgagne, [12]; Hoffman, [13]; Delmas, [14, 15]; Kotchen, [16]; Kim [17]; Bisore, [18], Simpson [19], Hamilton [20], Fergurson [21]) indicates that information availability affects consumer concerns and consequently the demand for products.

Energy is required to produce goods and services, and consumer pressure can affect the choices people make in terms of choosing goods and services associated with renewable or clean energy [15]. This same author [14] found that a deregulated industry where competition is incipient will be affected by consumer perception and sensitivity to the issue, favoring the insertion of renewable sources. 
Delmas [14] notes that the intense use of coal generation may inhibit this process because of its low cost. In the following section, we analyze the predominant sources of power in Brazil.

Kotchen [16] attempts to answer if simple, relatively low cost government programs can effectively promote voluntary initiatives, and whether such initiatives will continue to be effective if more centralized policies are required in future.

Are voluntary and mandatory initiatives complementary or substitutes? In our opinion, and likely the opinion of anyone who reads the 2013 CDP Report [22], all parties must be involved in the effort. According to Hamilton [2], the voluntary carbon market "represents a volume of over USD 100 million", and gives companies the tools they need to prepare for, and demonstrate leadership in GHG emission regulation. "This market is growing fast, perhaps doubling each year". Hamilton [20] also believes that a first step to go into a voluntary market is to measure the emissions that are the target of the effort, an opinion that is in line with this paper.

Ferguson [21], in a report for the US Environmental Agency, has a completely different view of the possibility that voluntary markets will succeed. He found that the main barriers to voluntary actions are the high cost to reduce emissions, and the complexity of the reporting disclosures.

Other authors share his pessimistic view of voluntary markets. Kim [17] reports that only projects with low marginal costs are likely to succeed, as the regulatory risk is usually considered high. This situation could be reversed if a "cap and trade" policy were used.

Finally, Hoffman [13] believes that voluntary markets could change the production chain as players opt for lower emission technologies, especially if there is some associated benefit, such as carbon credits. We would add to this the goodwill or favorable image associated with environmental marketing.

\section{THE BRAZILIAN ELECTRIC SYSTEM}

The Brazilian electric power system is characterized by a preponderance of hydroelectric power plants. These plants operate within an interconnected system, which is among the largest in the world, similar in size to the continent of Europe. This system consists of 64,000 miles of transmission lines, with planned additions of over 30,000 miles by 2021 [23]. Table 1 shows the composition of the installed generation capacity in Brazil as of January 2013 [24].

Table 1. Capacity of Brazilian power plants (January 2013)

\begin{tabular}{ccc}
\hline Power plants & Capacity [MW] & Share [\%] \\
\hline Hydropower (HPP) & $79,905.28$ & 65.99 \\
Small Hydro Power Plants (SHPP) (<30 MW) & $4,496.32$ & 3.71 \\
Wind Power Plants (WPP) & $1,888.38$ & 1.56 \\
Thermal Power Plants (TPP) & $32,777.00$ & 27.07 \\
Nuclear Power Plants (NPP) & $2,007.00$ & 1.66 \\
Solar Photovoltaic Power Plants (SPPP) & 7.58 & 0.01 \\
\hline Total & $121,081.56$ & 100 \\
\hline
\end{tabular}

Renewable sources of energy account for approximately $70 \%$ of capacity, while thermal power plants (including nuclear) account for the remaining 30\%. However, even in hydrologically unfavorable years such as 2012, most of the power is generated by 
hydroelectric plants. The disproportionate role in output stems from dispatching HPPs whenever reservoirs have enough water. It is uneconomical to dispatch power plants that use costly fossil fuels (remembering that these have both direct and indirect costs in the form of GHG emissions). Table 2 shows the technology breakdown for the total output of $513.81 \mathrm{TWh}$ in 2012 [25].

Table 2. Percent electricity produced by technology - Brazil, 2012

\begin{tabular}{cc}
\hline \multirow{2}{*}{ Plants } & $\begin{array}{c}\text { Production 2012 } \\
{[\%]}\end{array}$ \\
\hline HPP/SHPP & 85.9 \\
WPP & 0.6 \\
TPP & 10.4 \\
NPP & 3.1 \\
\hline
\end{tabular}

Currently Brazil is the largest nation that is highly dependent on hydroelectric power. Table 3 is a ranked list published in 2010 [6] of countries producing hydroelectricity. These statistics exclude exports from Paraguay to Brazil (from its share in the power plant of Itaipu Bi-national, usually of the order of $36 \mathrm{TWh}$ yearly).

This list places Brazil among the major countries with a large share of renewable electricity generation. However the acceptance of renewability as adequacy in relation to the environment is far from being accepted unanimously.

Table 3. Most significant producers of hydroelectricity

\begin{tabular}{ccc}
\hline Country & $\begin{array}{c}\text { Hydroelectricity } \\
\text { production 2010 [TWh] }\end{array}$ & $\begin{array}{c}\text { Share from } \\
\text { hydroelectricity [\%] }\end{array}$ \\
\hline China & 694 & 14.8 \\
Brazil & 403 & 80.2 \\
Canada & 376 & 62.0 \\
United States & 328 & 7.6 \\
Russia & 165 & 15.7 \\
India & 132 & 13.1 \\
Norway & 122 & 95.3 \\
Japan & 85 & 7.8 \\
Venezuela & 84 & 68.0 \\
Sweden & 67 & 42.2 \\
\hline
\end{tabular}

The debate over the impact of hydroelectric power plants occurs in the policy arena and in academic literature. Non-governmental organizations such as Greenpeace and the World Wildlife Fund (Movimento Gota D'água [27], Amazon Watch [28], Sant'Ana [29]) have presented a case against electricity from hydro sources. In addition, social movements and celebrities highlight concerns regarding the dams and reservoirs and their impact on the local population and environment (flora and fauna) ${ }^{\dagger}$.

\footnotetext{
${ }^{\dagger}$ NGOs include Brazil's MAB (Movimento dos Atingidos por Barragens) or Movement of People Affected by Dams (MAB). Celebrities include James Cameron, Arnold Schwarzenegger (AmazonWatch, 2011), and Susan Sarandon, to name a few.
} 
Within the academic community, a sampling of those arguing the case against Hydroelectric Power Plants (HPPs) includes several examples (McCully [30], Bermann [31], Cernea [32], McCormick [33], Fearnside [34]). For these reasons, the Designated National Authority normally does not consider large hydro plants as being emission-free. However the system is almost entirely interconnected, which leads to an important question regarding the reduction of GHG emissions in regulated and non-regulated markets: how can one separate the wheat from the chaff?

\section{Understanding the problem}

The problem of how to quantify the amount of greenhouse gases emitted by interconnected power systems is a recurring one, as these systems normally combine energy produced from different sources, some of them very carbon-intense, and others that may even be considered carbon-neutral. An example of a high greenhouse gas-emitting source would be a coal burning thermal plant. A carbon-neutral source would be a small-scale wind turbine, for instance.

However, as these systems are normally operated by an independent entity, dispatch decisions are based on criteria of system efficiency and supply security, and it is impossible to unequivocally associate the dispatch of a given plant and a specific consumer.

The UN Framework on Climate Change (UNFCC) stipulates that carbon intensity shall be calculated using a set of rules based on ACM-002 methodology for calculating the average grid emission used for Clean Development Mechanisms (CDM). The methodology used to calculate the average design emission for grids under the Clean Development Mechanism (CDM) available at http://cdm.unfccc.int/methodologies/DB/M0CSBFOF8RQG5I84XU5Y4WX0I5LHS1

In Brazil, the Designated National Authority, the entity assigned by Brazilian Law to be responsible for measures related to climate change in this country, publishes the official figures for average emissions by the Brazilian electric power grid. This calculation is updated monthly for official use in CDM projects (carbon credits) and for inventory purposes http://www.mct.gov.br/index.php/content/view/321144.html\#ancora

Although the methodology used for calculation is the same for clean development projects and inventory purposes, the values used for the former are substantially higher than those published for inventory purposes. This difference arises as calculations for carbon credit projects consider future emissions based on the expectation of new generating enterprises in the period considered for the project lifetime. In Brazil especially, there is a clear tendency towards a larger number of thermal power plants and the expectation is that emissions will increase going forward, which justifies a larger future emissions factor.

On the other hand, published emissions for inventory purposes reflect the realities of the actual generating plants dispatched. In years with less rainfall, which has been the case in 2013 and 2014, emissions are higher than they are in years with heavier rainfall. Emission factors for the Brazilian power grid are available on the Ministry of Science and Innovation Website.

The methodology described in our proposal is based on emission factors used for inventory purposes, as they reflect the actual consumption of electric power in each reference year for over 120 large electricity consumers.

The methodology to calculate avoided emissions described in this document has been used since 2011 by a portfolio of 120 electricity consumers who source part of their power from incentivized sources in the deregulated market. This portfolio includes companies in several different industries such as food, retail, electro-electronics, 
packaging, personal care and household cleaning, surgical supplies, construction, pulp paper, steel and metallurgy, textiles, leather, apparel, vehicles and auto parts

In the methodology used by the Brazilian Government, hydro plants of any size, biomass-fueled thermal power plants and wind farms are considered to be GHG neutral. Although it is a known fact that some hydro plants do emit greenhouse gases, the Brazilian Designated National Authority has determined that for accounting by the Brazilian electric power sector, all hydro plants shall be considered as having no GHG emissions.

Therefore, if it were possible to track the source of the power consumed one would be able to use a different emission factor for each source. In some cases, this would be higher than the average emissions of the National Interconnected System (SIN).

However, for operational strategy reasons this is impossible. Hydroplants may even be switched off to preserve water in the drier months, in which case the resulting energy deficit is offset by energy produced by thermal plants burning a range of fossil fuels.

\section{Proposal for modeling emission reductions}

By law, in Brazil small power plants using renewable resources and with low environmental impact have a financial incentive in the form of discounted energy transport rates (TUSD) or, in other words, they pay a lower fee for using the distribution systems. This incentive is determined by law $10.438 / 2002$ which provides for the sale of electricity, [24]:

"ANEEL shall stipulate a percent reduction of not less than $50 \%$ (fifty percent) to be applied to the fee for using the power transmission and distribution systems to carry marketed electricity produced by any of the means defined in item I of this article (item I defines: the use of hydro potential greater than 1,000 kW, up to and including 30,000 kW by independent or self-generators in a small hydro plant), as well as electric power produced from wind, biomass or qualified cogeneration operations, as per ANEEL regulations and within the power ranges stipulated in cited item I."

In short, all power plants that meet the highlighted characteristics in the law above are eligible for this incentive. These include Small Hydro Power Plants, Wind Power Plants and Biomass Fueled Thermal Plants, as well as qualified cogeneration plants. All must meet the criteria of small size and necessarily be smaller than $30 \mathrm{MW}$.

Here there is a two-way match. All of the incentivized plants use renewable sources and are considered emission-neutral. Thus, by proving that the energy purchased by the consuming entity is eligible for a discount on the TUSD fee, one may infer that the entity is purchasing energy from a GHG neutral source.

The problem remains as to how to ensure that the energy used by the unit actually comes from this set of incentivized power plants.

This is guaranteed by the Electric Energy Trading Chamber, or CCEE. The CCEE is the official body responsible for supervision and control of electric energy trades between distributors, traders, free consumers and generators in Brazil. Transactions based on incentivized energy are eligible for discounted transport fees. This discount is allocated to all other electric power consumers. ANEEL assigned to CCEE the responsibility for making sure the energy traded was generated by a source eligible for the discounts provided by law. Since January 2009, the CCEE has consistently published an indicator known as the "discount matrix", with is associated with each consumer with registered contracts to purchase incentivized energy.

\footnotetext{
*All of them are clients of Comerc Energia. The methodology described herein was developed by Sinerconsult Consultoria, Treinamento e Participações.
} 
This matrix is a reliable, traceable, auditable and public measure of the energy consumed from an incentivized, and therefore GHG neutral source.

Thus, this methodology indirectly uses an official source to determine what percentage of the power consumed by a specific free consumer actually comes from a GHG neutral source.

One should remember that there is always the possibility that a given source will be unable to produce all of the energy sold. In such situations, the generator or trader must purchase energy from third parties to honor its agreements and provide the energy it sold but is unable to deliver. If this "replacement" energy comes from a non-incentivized source, the consumer loses the right to discounted transmission fees in direct proportion to the non-incentivized volume supplied. The loss of this discount is made official by the CCEE, the entity legally and formally responsible for overseeing this type of operation.

Thus the proposed methodology uses an indirect but official inspection, which identifies the proportionality of the energy with incentives and thus from sources that have zero emissions or are GHG neutral.

This methodology determines how much of the energy consumed is eligible for a transport discount, and reduces the emissions published by the government for that particular month by a proportional amount.

The outcome is supported by the reliability of two official sources, one the amount of GHG emitted by the grid, and another the exact volume of electricity consumed that was generated from renewable, GHG neutral sources. This reliability extends to the period during which the data is calculated, as both indicators are calculated for each calendar month, avoiding any distortions related to the period of calculation of these indicators.

\section{METHODOLOGY}

The method used to calculate these numbers is described below. It is based on the trading chamber (CCEE) "ME001" (energy consumed) and "EI002" (TUSD incentive discount) reports.

First the weekly consumption of energy reported in ME001 (energy consumed) reports is added up to come up with the total for the month. The amount of energy traded at a given percent discount (TUSD or wire discount) is added and divided by the total volume, to arrive at:

$$
T D=\frac{\sum V E \times D}{\sum V E}
$$

where:

- $T D$ is the Total Discount;

- $V E$ is the Volume of Energy;

- $D$ is the Discount.

Consumption is then multiplied by the discount to arrive at the incentive that applies to the volume of energy:

$$
M I A E=\sum W E \times T D
$$

where:

- $M I A E$ is the Monthly Incentive Applicable Energy;

- $W E$ is the Weekly Consumption. 
The difference between monthly consumption and the amount of incentivized energy is then used to calculate the GHG emissions avoided each month, reported as tons of $\mathrm{CO}_{2}$ equivalents. This is calculated as a specific emission factor such as tons of $\mathrm{CO}_{2 \mathrm{eq}} / \mathrm{MWh}$ :

$$
A E=(T M C-I A E C) \times E F
$$

where:

- $A E$ are the Avoided Emissions;

- $T M C$ is the Total Monthly Consumption;

- $I A E C$ is the Incentive Applicable Energy Consumption;

- $E F$ is the Emission Factor.

The procedures described herein abide by the generally accepted principles for calculating inventory, which are Relevance, Universality, Precision, Transparency and Consistency. Calculating avoided GHG emissions is a simple and reliable process if one has access to the customers reports issued by the CCEE regarding electricity consumption, specifically ME001 and EI 002.

\section{CONCLUSION}

The results obtained are substantial and represent a pioneering initiative in voluntary measures to reduce GHG emissions in Brazil.

Table 4 presents the results of 120 different companies that have been using this methodology since 2011 .

Table 4. Certification results for the portfolio of COMERC clients, 2011

\begin{tabular}{ccc}
\hline Segment & Ton $\mathrm{CO}_{2 \mathrm{eq}}$ & $\begin{array}{c}\text { Equivalent } \\
\text { reforestation (Trees) }\end{array}$ \\
\hline Food & 36,217 & $253,519.9$ \\
Retail & 3,935 & $27,544.8$ \\
Electro electronics & 793.2 & $5,552.2$ \\
Electromechanical & $3,000.6$ & $21,004.5$ \\
Packaging & $3,274.3$ & $22,920.4$ \\
Personal care and HH & $1,373.6$ & $9,615.0$ \\
cleaning & 43.6 & 305.2 \\
Surgical supplies & $4,569.4$ & $31,985.8$ \\
Civil construction & $2,614.2$ & $18,299.6$ \\
Pulp \& paper & $1,738.8$ & $12,171.8$ \\
Steel and metallurgy & $6,653.3$ & $46,572.9$ \\
Textile, leather and & $1,491.4$ & $10,439.7$ \\
apparel & 630.1 & $4,410.4$ \\
Vehicles and auto parts & $66,334.6$ & $464,342.2$ \\
Other & &
\end{tabular}

We have also calculated the equivalent amount of reforestation required to yield the same result. This should make the methodology easier for the lay public to understand, and help customers using this methodology issue sustainability reports, thus making the 
methodology more attractive. For this conversion, we used a reforestation project in Brazil that has received carbon credits under CDM procedures.

The procedures described herein abide by the generally accepted principles for calculating inventory, which are Relevance, Universality, Precision, Transparency and Consistency. Calculating avoided GHG emissions is a simple and reliable process if one has access to the confidential reports issued by the CCEE regarding electricity consumption, specifically ME001 and EI 002.

This methodology fills a gap in certification of avoided GHG emissions in Brazil, and may be a first step in an official certification initiative.

\section{REFERENCES}

1. Solomon, S., Qin, D., Manning, M., Chen, Z., Marquis, M., Averyt, K. B., Tignor, M. and Miller, H. L., (eds.), Contribution of Working Group I to the Fourth Assessment Report of the Intergovernmental Panel on Climate Change, Cambridge University Press, Cambridge, 2007.

2. Mann, M. E. and Jones, P. D., Global Surface Temperatures over the Past Two Millennia, Geophysical Research Letters, Vol. 30, No.15, pp 5-1,5-4, 2003, http://dx.doi.org/10.1029/2003GL017814

3. Mann, M., Zhang, Z., Hughest, M. K., Bradley, R. S., Miller, S. K., Rutherford, S. and Ni, F., Proxy-based Reconstructions of Hemispheric and Global Surface Temperature Variations over the Past Two Millennia, Proceedings of the National Academy of Science of the USA, Vol. 105, No.36 pp 13252-13257, 2008, http://dx.doi.org/10.1073/pnas.0805721105

4. Dell, M., Jones, B. F. and Olken, B. A., Climate Change and Economic Growth: Evidence from the Last Half Century, Working Paper 14132, National Bureau of Economic Research, 2008, http://dx.doi.org/10.3386/w14132

5. Thompson, L. G., Climate Change: The Evidence and our Options, The Behaviour Analyst, Vol. 33, No. 2, pp 153-170, 2010.

6. National Research Council, Climate Change: Evidence, Impacts and Choices, USA, 2012, http://nas-sites.org/americasclimatechoices/files/2012/06/19014_cvtx_R1.pdf, [Accessed: April-2013].

7. Lal, D., The New Cultural Imperialism: The Greens and Economic Development, UCLA Department of Economics, Working Paper 814, 2000.

8. Carter, R. M., Freitas, C. R., Goklany, I. M., Holland, D. and Lindzen, R. S., The Stern review: A Dual Critique, World Economics, Vol. 7, No. 4 pp 165-230, 2006.

9. Idso, C. and Singer, F. (orgs.), Climate Change reconsidered: 2009 Report of the Nongovernmental International Panel of Climate Change (NIPCC), The Heartland Institute, USA, 2009.

10.Milloy, S., Green Hell, Regnery Publishing Inc., USA, 2009.

11.Lomborg, B., The Skeptical Environmentalist-measuring the Real State of Earth, Cambridge University Press, 2010.

12.Desgagné, B. S. and Gozlan, E., A Theory of Environmental Risk Disclosure, Journal of Environmental Economics and Management, Vol. 45, pp 377-393, 2003, http://dx.doi.org/10.1016/S0095-0696(02)00056-6

13.Hoffmann, A., Climate Change Strategy: The Business Logic behind Voluntary Greenhouse Gas Reductions, Working Paper Ross School of Business, Michigan 2004.

14.Delmas, M., Russo, M. V. and Montes-Sancho, M., Deregulation and Environmental differentiation in the Electric Utility Industry, Strategic Management Journal, Vol. 28, pp 189 - 209, 2007, http://dx.doi.org/10.1002/smj.578 
15.Delmas, M., Montes-Sancho, M. and Shimshack, J., Information Disclosure Policies: Evidence from the Electricity Industry, Economic Inquiry, Vol. 48, No. 2, pp 483-498, 2010, http://dx.doi.org/10.1111/j.1465-7295.2009.00227.x

16.Kotchen, M., Climate Policy and Voluntary Initiatives: An evaluation of the Connecticut Clean Energy Communities Programs, Working Paper 16.117, National Bureau of Economic Research, 2010.

17.Kim, E. H. and Lyon, T. P. Strategic Environmental Disclosure: Evidence from DOE's Voluntary Green House Gas registry, Journal of Environmental Economics and Management, Vol. 61, pp 311-326, 2011, http://dx.doi.org/10.1016/j.jeem.2010.11.001

18.Bisore, S. and Hecq, W., Regulated (CDM) and Voluntary Carbon Offset Schemes as Carbon Offset Markets: Competition or Complementarity? Centre Emile Bernheim, Solvay Brussels School of Economics and Management, Working Paper, 2012.

19.Simpson, P., (co-ord.), CDP Global 500 Climate Change report 2012, https://www.cdproject.net/CDPResults/CDPGlobal500-Climate-Change-Report 2012.pdf , [Accessed: May-2013]

20.Hamilton, K., Schuchard, R., Stewart, E. and Waage, S., Off Setting Emissions: A Business Brief on the Voluntary Market, Ecosystem Marketplace, 2008, http://www.bsr.org/reports/BSR_Voluntary-Carbon-Offsets-2.pdf,

[Accessed: May-2013]

21.Fergurson, J., Harris, J., Hart, J. S., Ramakrishnan, K., Thompson, T. and Weber, S., Voluntary Greenhouse Gas Reduction Programs have Limited Potential, Report 08-P-0206, US Environmental Agency, Report 08-P-0206, 2008.

22. CDP, Climate Disclosure project, CDP Climate Change Report 2013, https://www.cdp.net/CDPResults/CDP-SP500-climate-report-2013.pdf, [Accessed: May-2013].

23.EPE- Empresa de Pesquisa Energetica, www.epe.gov.br, [Accessed: May-2013]

24.ANEEL - Agência Nacional de Energia Elétrica, www.aneel.gov.br, [Accessed: January-2013]

25.ONS - Operador Nacional do Sistema, www.ons.org.br, [Accessed: January-2013]

26.IEA International Energy Agency; Technology Roadmap Hydropower, 2012, www.eia.org, [Accessed: January-2013]

27. Movimento Gota d'agua, É a gota d'água, http://www.youtube.com/watch?v=WJkKoKah08A, [Accessed: February-2013]

28. Amazon Watch, James Cameron brings Arnold Schwarzenegger to Amazon to see first hand a Battle between Old and New Energy, 2011, http://amazonwatch.org/news/2011/0326, [Accessed: February-2013]

29.Sant'Ana, P. H. M., (coord.), Além das grandes Hidroelétricas: políticas para fontes renováveis de energia elétrica no Brasil- Sumário para tomadores de decisão, http://d3nehc6yl9qzo4.cloudfront.net/downloads/alem_de_grandes_hidreletricas_sumar io_para_tomadores_de_decisao.pdf, [Accessed: February-2013]

30.McCully, P., Silenced Rivers-The Ecology and Politics of Large Dams, London, ZED Books, 2001.

31.Bermann, C., Energia no Brasil: para quê? para quem? - Crise e alternativas para um país sustentável, São Paulo: Editora Livraria da Física / FASE v. 01. 139 p, 2002.

32.McCormick, S., The Brazilian Anti-dam movement: Knowledge, Contestation as Communicative action, Organizational \& Environment, Vol. 19, No. 3, pp 321- 346, 2006, http://dx.doi.org/10.1177/1086026606292494

33.Cernea, M. M., Social Integration and Population displacement: The Contributions of Social Sciences, International Social Science Journal, No. 43, pp 91-112,1995. 
34.Fearnside, P., A triste história de Belo Monte III: do EIA RIMA rejeitado ao aval do Congresso, 2009, Blog do http://colunas.globoamazonia.com/philipfearnside/, [Accessed: February, 2013]

Fearnside,

Paper submitted: 22.04 .2014

Paper revised: 21.07.2014

Paper accepted: 16.08 .2014 